\title{
CULTURA VISUAL E EDUCAÇÃO: CARTOGRAFIAS AFETIVAS E COMPREENSÃO CRÍTICA DAS IMAGENS
}

\author{
LUTIERE DALLA VALLE \\ UNIVERSIDADE FEDERAL DE SANTA MARIA \\ SANTA MARIA, RIO GRANDE DO SUL, BRASIL \\ LUTIERE@DALLAVALLE.NET.BR
}




\section{CULTURA VISUAL E EDUCAÇÃO: CARTOGRAFIAS AFETIVAS E COMPREENSÃO CRÍTICA DAS IMAGENS}

Resumo: Este texto propõe discutir e analisar a potência das imagens como (con)formadoras das identidades contemporâneas e suas problemáticas no âmbito da educação. Objetiva articular experimentações de análise crítica e performativa diante da hegemonia cultural. Embasam a escrita Metodologias Visuais a partir de Fernando Hernández e autores, sob o enfoque da Perspectiva Educativa da Cultura Visual.

Palavras Chave: Cultura visual; Educação crítica; Imagens.

\section{CULTURA VISUAL Y EDUCACIÓN: CARTOGRAFÍAS AFECTIVAS Y EMANCIPACIÓN CRÍTICA}

Resumen: Este texto propone discutir y analizar la potencia de las imágenes como (con)formadoras de las identidades contemporáneas y sus problemáticas en el ámbito de la educación. Objetiva articular experimentaciones de análisis crítica y performativa delante la hegemonía cultural. Metodologías Visuales a partir de Fernando Hernández y autores desde la Perspectiva Educativa da Cultura Visual basan la escrita.

Palabras Clave: Cultura visual; Educación crítica; Imágenes.

\section{VISUAL CULTURE AND EDUCATION: AFFECTIVE CARTOGRAPHY AND CRITICAL POSITION OF IMAGES}

Abstract: This text proposes to discuss and analyze the power of images as contemporary identities references and complexity in the education. The aims to articulate experiments of critical and performative analysis of the cultural hegemony. The visual methods used from Fernando Hernández and others from the Educational Perspective of Visual Culture.

Key-word: Visual culture; Critical education; Images.

\section{INTRODUÇÃO}

(... ) o ato de ver não acontece num vazio cultural; ao contrário, sempre acontece em contexto, e contexto orienta, influencia e/ ou transforma o que vemos. Por esta razão, ver é - deve ser - um processo ativo e criativo. (MARTINS; TOURINHO, 2011, p. 54)

Inicio este texto com os argumentos de Raimundo Martins e Irene Tourinho, pesquisador e pesquisadora da Universidade Federal de Goiás, que tem produzido vários artigos e livros na interlocução arte, cultura visual e edu- 
cação, no que diz respeito às práticas culturais do olhar. Para ambos, é imprescindível pensarmos processos de formação (principalmente no âmbito da educação, e em todos os níveis) levando em consideração as visualidades que nos atravessam diariamente e influenciam as formas como interpretamos o mundo, bem como às relações simbólicas que estabelecemos.

Assim como o autor e autora citados, igualmente tenho dedicado interesse como pesquisador, principalmente por estar vinculado à formação de professores e professoras, no campo das artes visuais, pedagogia e educação especial no contexto universitário. Ainda assim, tenho flertado com a comunicação, a engenharia, entre outras ações pontuais e interdisciplinares que tenho sido convidado a contribuir a partir das imagens e sua potência pedagógica. E é sempre uma grata surpresa perceber quão profícuas são as relações transdisciplinares que o campo dos estudos visuais e suas metodologias possibilitam.

Ao reiterar que as percepções que temos dos objetos com os quais interagimos cotidianamente não são neutrais, somos atravessados pelos dispositivos culturais que fazem com que um objetivo, ou uma prática cultural, logre sentido. Quando um artefato visual produzido por determinado contexto cultural nos seduz ou causa estranhamento, o ato de 'gostar' ou 'não gostar' pode introduzir uma concepção prévia da compreensão que dispomos naquele momento (alimentada por experiências antecedentes).

Portanto, considerar as relações afetivas que estabelecemos com as imagens (de prazer ou repulsa) podem ser, sob estas premissas, de grande potência para movimentar a produção de sentido. O caráter sedutor das imagens é presente na cultura popular e referência a moda, o comportamento, todas as esferas interfaces com as distintas camadas sociais, tendo como foco o consumo. Produzimos e consumimos imagens desde os primórdios das atividades humanas: seres narrativos que desde o princípio manifestam apreço pelas estórias, pelas metáforas, pelas distintas formas de comunicar e expressar o que acontece e nos interpela.

Para Jerome Bruner "os seres humanos não terminam em sua própria pele, são extensão da cultura”. (BRUNER, 1991: 28), sendo, portanto, interpelados por incansáveis marcadores sociais que definem, legitimam e regem as experiências humanas em todos os contextos e práticas coletivas. Transitamos por diversos espaços, construímos nossas convicções sob a ótica que nos permitimos a partir 'de onde nossos pés pisam' (Leonardo Boff em a Águia e a Galinha: uma metáfora da condição humana. BOFF, 2006). 
Neste contexto, cartografias afetivas (aludindo ao título deste artigo) refere-se ao mapeamento dos desejos, ou seja, parte da identificação daquelas referências visuais (populares) que envolvem nossas experiências com as imagens oriundas das narrativas fílmicas, da publicidade, da moda, das artes em geral. Reconhecer a relação do 'prazer visual' com o olhar culturalmente constituído e como se dá o processo de legitimação e consumo, nos ajuda a compreender que estes prazeres não são universais, muito menos intrínsecos ou 'naturais' e, portanto, não afetam a todos os grupos sociais da mesma intensidade. Menos ainda: não são capazes de disparar as mesmas relações afetivas (no sentido do que nos afeta, seja o caráter de aproximação ou distanciamento), pois há sempre um viés interpretativo que interpela o sujeito que olha.

Diante destas considerações iniciais, o recorte desta escrita (entre tantas possibilidades) dedica-se a discutir e analisar a potência das imagens como dispositivos de emancipação e transgressão nos contextos de formação docente. Isto é, partindo da perspectiva de que estamos constantemente submetidos aos imaginários visuais que determinadas culturas nos impõem, a partir da prática de colocar imagens em relação podemos configurar estratégias de subversão, análise crítica e performativa.

\section{METODOLOGIAS VISUAIS: TEMPORALIDADES MÚLTIPLAS E CON- TAMINAÇÕES CONCEITUAIS}

Como dito anteriormente, nossa relação com a produção e o consumo de imagens é parte de nossas aquisições cognitivas: arquitetamos códigos de representação, negociamos métodos de fabricação, compartilhamos procedimentos técnicos e nos organizamos em sociedade, mediados por uma infinidade de artefatos que criamos para tornar nossas vidas repletas de sentido. Inventamos noções de tempo, cunhamos sistemas complexos para as linguagens (artísticas, literárias, matemáticas, entre tantas), bem como regras e normas para viver em sociedade. Ou seja, atravessados pelas relações culturais, nos adaptamos aos códigos culturais com os quais aprendemos a nos relacionar e compreender o mundo, desde o nascimento à fase adulta. E as imagens seguem em diálogo com o tempo vigente, apresentando-nos visões (e versões) das múltiplas realidades. Se as primeiras manifestações artísticas surgiram para atestar nossa capacidade humana de representação, as imagens ‘do nosso tempo' seguem acompanhando nossas incertezas e dúvidas diante da vida contemporânea ao evidenciar imagens 
polissêmicas, arbitrárias, complexas e que nos exigem posicionamento crítico e ativo para não sermos submergidos pela cultura dominante.

Muitas das imagens 'do nosso tempo' lidam com as precariedades e contradições do mundo que habitamos, onde nada é fixo. Convivemos com a liquidez infinita e conceitual das relações humanas e dos afetos: vimos desmoronar constantemente noções de verdades que eram ditas imutáveis. Escorreram entre nossos dedos os modelos canônicos dirigidos ao campo das visualidades, assim como esvaeceram-se as estruturas formais de análise a partir dos discursos prontos. Talvez, porque não mais seja possível falar em verdades. Ou ainda, pelo fato de que o que mais nos provoque seja justamente a perspectiva do espelho proposta por grande para das imagens contemporâneas: apresentam-se como reflexo das nossas atitudes, ações no mundo e formas de articular o conhecimento acumulado. Para Raimundo Martins:

Contra uma homogeneidade metodológica que é histórica, é necessário pensar em redes, em rizomas brotados do tempo e espaIhados nos espaços para explorar a profusão de temporalidades. Metodologias visuais não são uma fórmula, um texto, uma língua, ou uma linguagem que enuncia algo, mas ideias, sentidos, percepções e imaginação que se constroem, se performam e se articula imageticamente. (MARTINS, 2013, p. 95)

Ainda de acordo com o autor, quando as imagens assumem o papel de disparadoras, podem contribuir para problematizar o campo social no que diz respeito às questões de gênero, credo, liberdade, respeito, cidadania e educação. Através do exercício da indagação 'o que vejo de mim' nestas representações, são ativadas junto à pergunta, igualmente, "o que não vejo" das minhas experiências. Ou seja, tomando as relações de poder que se estabelecem e se articulam através das imagens e que são responsáveis pelas representações do que 'pode' ser visto e o que deverá permanecer invisível, uma infinita rede de conexões se abre à nossa frente.

Incita-nos abandonar modelos prescritivos de observação e deleite para implicar-nos com diferentes formas de compreensão. Isto é, nos convoca a ativar todo o tipo de relações possíveis: táteis, imersivas, participativas, colaborativas, corpóreas, performáticas, virtuais, discursivas, literárias, enfim, plurais, híbridas e transdisciplinares.

Da mesma forma, fomentando-nos o debate acerca das relações entre saberes e problemáticas atreladas à identidade e à subjetividade, ao poder, 
às políticas culturais, à memória individual e coletiva.

\subsection{Acionando conceitos: a perspectiva educativa da cultura visual}

Na busca por situar a perspectiva de estudos da cultura visual, podemos começar dizendo que um dos aspectos de maior relevância para este enfoque é partir de que não existe uma 'pureza' natural que envolve o campo imagético. Ao contrário, o que vemos, resulta de embates, negociações enraizadas na cultura, onde uma gama de signos e símbolos oriundos de várias disciplinas se inscrevem. Neste interim, as imagens não estão livres de situações de mascaramento e silenciamento - ainda que no campo simbólico. Assim, a perspectiva educativa da cultura visual nos convida a abandonar dogmas e relações hierárquicas para desenvolver um posicionamento crítico, experimentar contextos mutáveis e plurais ao pensar e propor as visualidades que participam dos nossos entornos sociais.

A metáfora do rizoma (pelo viés do que propõem Deleuze e Guattari, em HERNÁNDEZ, 2007) pode ser uma alternativa para argumentar sobre esta abordagem: cresce e ramifica-se de forma complexa em todos os sentidos, conectando-se à diversos campos de forma não hierarquizada. Inserida no campo dos estudos visuais (MOXEY, 2004; HERNÁNDEZ, 2013) caracteriza-se, principalmente por seu caráter 'adisciplinar' (HERNÁNDEZ, 2007), interpretativo, e não se refere a uma teoria, ou objeto de estudo específico, mas a um campo que se constitui a partir dos atravessamentos entre distintas disciplinas que examinam as práticas culturais do olhar. Por isso, a metáfora do rizoma proposto seja mais adequada ao referir-se ao campo. Como um guarda-chuva ao qual se incluem imagens e artefatos do passado e presente para pensar como nos vemos e somos vistos (HERNÁNDEZ, 2007). Ou seja, uma perspectiva emergente frente às tecnologias visuais que trazem à tona a imagem como dispositivo do olhar, sobretudo na atualidade, onde são potencializadas nossas relações com o mundo simbólico por meio dos sistemas digitais de representação e consumo. Conforme o quadro n. 01, podemos perceber visualmente um mapeamento dos campos disciplinares que podem estabelecer interlocuções com a perspectiva de estudos da cultura visual. 


\section{Perspectiva de estudos da cultura visual: RIZOMA}

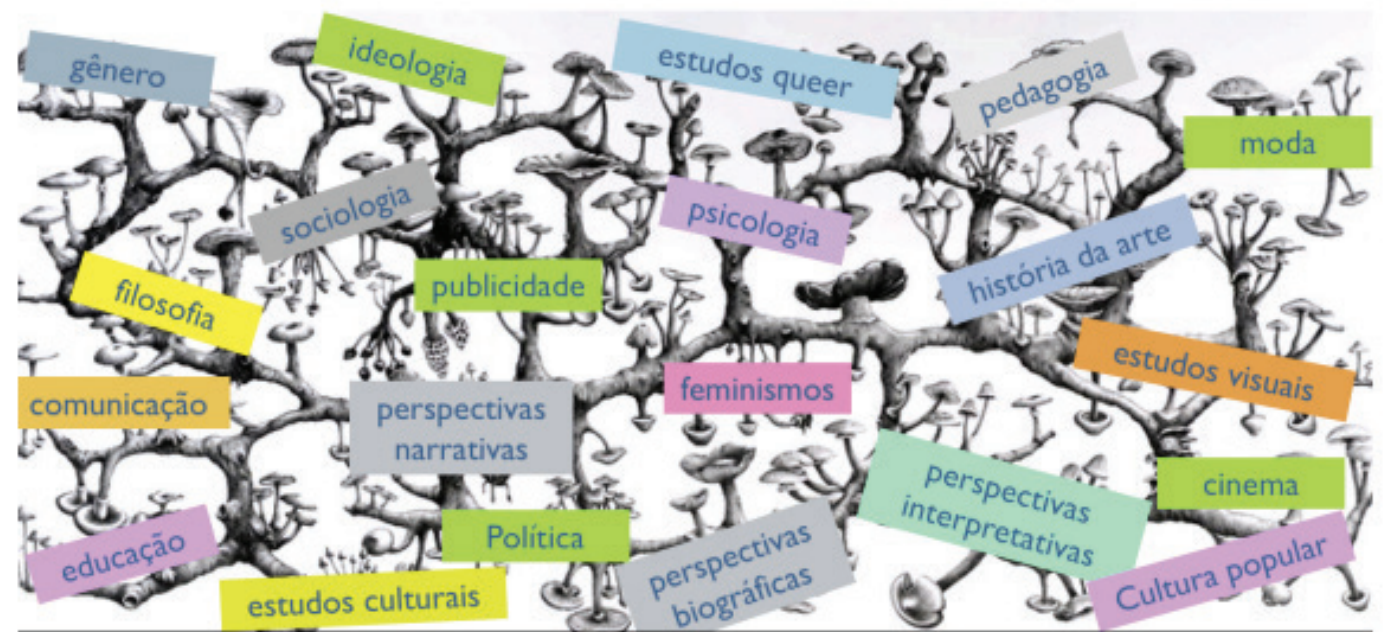

Fonte: elaboração do autor

Portanto, quando abordamos a perspectiva educativa da cultura visual, estamos falando de uma diversidade de práticas e interpretações críticas em torno das relações entre as posições subjetivas e as práticas culturais e sociais do olhar que emergem dos variados campos disciplinares. Ou seja, dos artefatos visuais que são produzidos pela cultura e que nos ensinam modos de ser e atuar - desde uma vinheta de abertura, às estruturas narrativas presentes nos filmes, nas tramas novelísticas, seriados, videoclipes, propagandas, outdoors, campanhas publicitárias.

Partindo da concepção de que noções de verdade e realidade igualmente correspondem a construções sociais, culturais e históricas, sob o estudo da cultura visual podemos exercitar o distanciamento necessário para uma posição crítica e emancipatória em relação às concepções estáveis e inflexíveis que normalmente são dadas. Para Fernando Hernández, a contribuição principal da perspectiva da cultura visual consiste em propor uma mudança de foco do olhar e do lugar de quem vê. (HERNÁNDEZ, 2007, p.35). Esse distanciamento nos permite repensar o que é normativo a fim de examinar de onde surgiram e como determinadas normas não correspondem a uma única verdade, mas consistem em referências datadas, localizadas e impregnadas de ideologias que encontram respaldo na cultura.

Para dar conta das experiências visuais (principalmente no momento atual em que as imagens digitais habitam cada vez mais as nossas práticas cotidianas), as metodologias visuais no campo da pesquisa rompem e pro- 
blematizam as metodologias hegemônicas em que a escrita parece seguir como o principal modo de fazer pesquisa. Neste sentido, a cultura visual preocupa-se com o protagonismo do sujeito que interpreta, bem como os relatos visuais que formula como resposta às problematizações que o acompanham. Para Hernández:

(...) o debate em torno do que denominamos por cultura visual, converge uma série de propostas intelectuais em termos das práticas culturais relacionadas ao olhar e às maneiras culturais de olhar na vida contemporânea, especialmente sobre as práticas que favorecem as representações de nosso tempo e levam-nos a repensar as narrativas do passado. (HERNÁNDEZ, 2007, p. 22)

Assim, o uso de imagens artísticas como potência para pesquisas no contexto acadêmico é também emergente, sobretudo na literatura brasileira. Pelo viés dos Estudos Visuais e da Cultura Visual, ainda são recentes as publicações que tomam as visualidades como dispositivos e que consideram relatos visuais como uma possibilidade de produzir conhecimento para além da escrita acadêmica. Valorar e conceber o uso de imagens oriundas do campo das artes visuais e sua conexão com outras áreas do conhecimento, configuram-se potentes estratégias metodológicas de investigação. A Investigação Baseada nas Artes (IBA), como metodologia visual de pesquisa configura-se importante referência e com esclarecedoras contribuições:

O desafio da IBA é poder ver as experiências e os fenômenos aos que dirige sua atenção a partir de outros pontos de vista e formular questões que outras maneiras de fazer pesquisa não são capazes de realizar. De certa forma, o que a IBA pretende é sugerir mais perguntas que oferecer respostas. Quando pensamos na IBA só podemos fazê-lo considerando a utilização das imagens ou representações artísticas visuais ou performativas como elemento essencial das experiências dos sujeitos. (HERNÁNDEZ, 2013, P. 45)

Portanto, desenvolver pesquisas a partir das metodologias visuais consiste em uma abordagem crítica, criativa e inventiva. $O$ desafio do pesquisador, ou pesquisadora, a partir destas metodologias, difere dos processos da pesquisa tradicional: neste caso, baseia-se no fato de que os resultados não são encontrados, mas construídos, assim como a prática interpretativa. E é a partir de perspectivas conectivas que são estabelecidas as análises da trajetória investigativa produzida, localizando as imagens no 
contexto dos processos sociais que produzem sentido e significado. Implica, por exemplo, conceber resultados que não são mensuráveis, mas alcançados a partir de sua natureza relacional, em diálogo com o contexto social.

Conectividade, multiplicidade são palavras que precisam estar presentes, uma vez que o foco está no que acontece 'entre uma imagem e outra(s)', ou seja, a partir das redes de conexão que se estabelecem e produzem um novo relato, tecendo novos desdobramentos para quem olha determinado objeto. Em decorrência de seu caráter movediço, é importante reconhecer sua heterogeneidade, as diferentes circunstancias de produção imagética e a variedade de elementos culturais e sociais que respaldam as relações de interpretação. Assim, ao adotar esta posição, somos impelidos a examinar a constituição de padrões, das estruturas hegemônicas, dos discursos prontos em busca da compreensão crítica como prática social efetiva. Da mesma forma, a esmiuçar repertórios visuais implícitos imbuídos de crenças e valores acumulados como potencializadores da formação crítica e emancipadora.

\subsection{Colocando Imagens em relação: disparadores que movi- mentam o pensamento}

No terreno simbólico, Jerome Bruner (1991) revela uma concepção do sujeito a partir das relações culturais que o atravessam e o constitui. Contingências da existência que são cruciais e definem formas de ser e atuar no mundo e inserem-se nas comunidades de discursos às quais participamos. E toda vez que um artefato provoca rupturas - ainda que muito pequenas - surgem desconfortos que fazem brotar vias de experimentação e movimentam o pensamento em direção ao caráter inventivo. Ao referenciar Gertz, o autor afirma que "não existe uma natureza humana independente da cultura" (BRUNER, 1991: 28) pois, em cada contexto cultural, nos empenhamos em sistematizar, organizar, nomear, apreender relações formais de representação, características próprias do olhar humano - o que nos remete ao olhar cultural. Para Zygmunt Bauman:

A cultura é o posto de abastecimento do sistema social; ao penetrar nos sistemas de personalidade, no curso dos esforços de manutenção de padrões (ou seja, sendo internalizada no processo de socialização), ela garante a intelectualidade consigo mesmo do sistema ao longo do tempo - mantém a sociedade funcionando em sua forma distintivamente reconhecível. (BAUMAN, 2012: 25) 
Neste sentido, problematizar o campo das imagens nos permite esboçar relações a partir de experiências subjetivas e coletivas, pautadas sobretudo por relações de poder que explicita ou implicitamente configuram estas relações. Os contornos sugeridos pela vida vivida multifacetada, plasmada em visualidades, provocam nosso olhar, conformam nossa humanidade alicerçada nos valores sociais/culturais agenciados, legitimados e comumente aceitos.

Diante das nossas experiências estéticas/sensíveis, o diálogo com as imagens movimenta reflexões para além da complexidade formal e visual: nos estimula a perceber valores culturais, ideológicos e sociais que em outros formatos, quiçá não perceberíamos com tamanha potência e afecção, devido à sua natureza relacional e subjetiva. Assim, a prática de 'colocar imagens em relação' configura-se estratégia metodológica de investigação para compreender o que acontece quando 'friccionamos' algumas representações visuais. Ao examinarmos o caráter simbólico, elementos visuais que constituem determinadas imagens, assim como aspectos que dizem respeito ao contexto de produção, legitimação, circulação (ou negação) e consumo, podem oferecer-nos pistas para uma análise mais ampla e complexa que envolve sua significação. $O$ que faz com que a partir destas imagens 'em fricção' adquiram o status de 'disparadoras' do pensamento ao incitar o jogo e a configuração de redes que conectam conhecimentos prévios, novas perguntas e novos caminhos investigativos.

Perguntar por que aceitamos 'naturalmente' algumas imagens em detrimento de outras, implica problematizar onde residem as definições de gosto, prazer e repulsa, e podem funcionar como dispositivos afetivos que partem daquilo que está visível na imagem. O que, de modo geral, está atrelado às significações coletivas, ao modo como aprendemos a ver. $\mathrm{Na}$ sequência, vale examinar os critérios que utilizamos para julgar, classificar e nomear o que vemos, contribuem para analisarmos criticamente quais são os repertórios que habitam nossos imaginários.

Neste sentido, abordarei algumas experimentações a partir de imagens que intencionalmente selecionadas como disparadoras. Os três agrupamentos apresentados, consistem em 'argumentos visuais' que tenho utilizado em algumas disciplinas com as quais costumo trabalhar na universidade. Os exercícios (aqui chamados de experimentações 1, 2 e 3) correspondem ao modo como articulamos inicialmente as metodologias visuais de pesquisa como disparadoras. Nestas experimentações, em geral, proponho 
algumas fricções como ponto de partida lançadas aos grupos para que possam, a partir destas vivências, elaborarem seus próprios relatos visuais e inquietações.

\subsubsection{Experimentação 1: compreensão crítica e performativa das imagens}

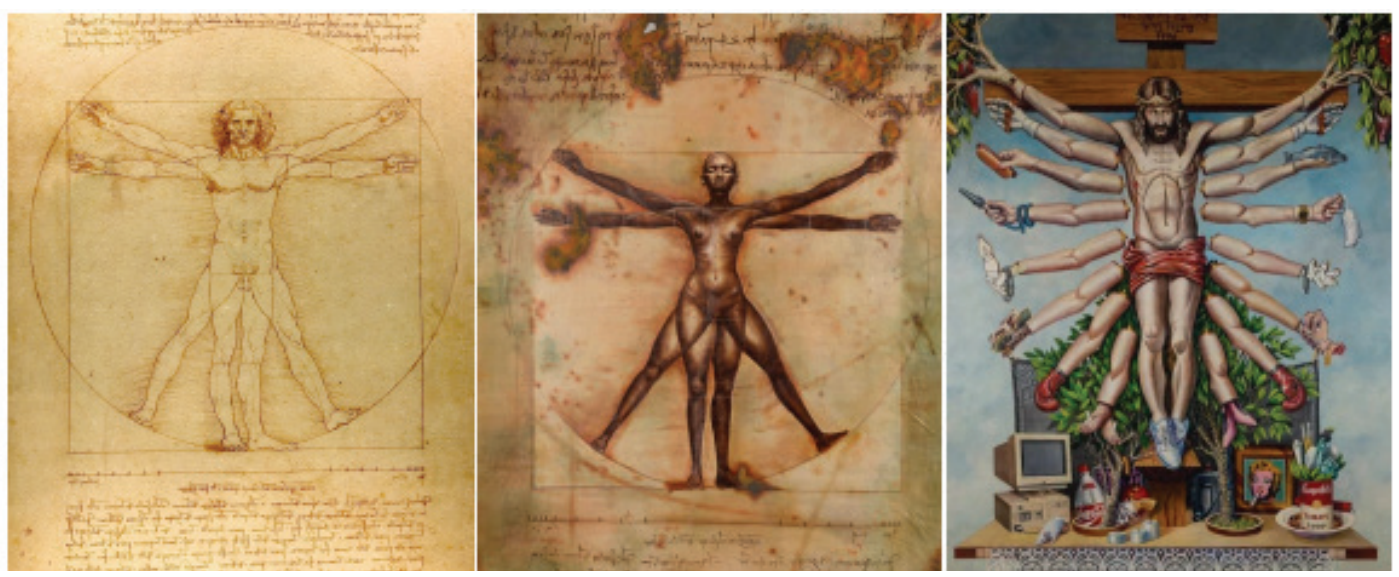

Figura 1: Vitruvian Man, 1490, Leonardo Da Vinci

Fonte: Disponível em: <https://www.leonardodavinci.net/the-vitruvian-man.jsp>.

Acesso em: 02 abr. 2020.

Figura 2: The Virtuous Woman, 2017- Harmony Rosales

Fonte: Disponível em: <https://www.harmoniarosales.com/>. Acesso em: 02 abr.

2020.

Figura 3: Cruzando Jesus Cristo com o Deus Shiva", Fernando Baril, 1996. Obra censurada na Exposição Queermuseu, Porto Alegre, 2017.

Fonte: Disponível em: <https://revistagalileu.globo.com/Cultura/noticia/2017/og/o-que-representam-obras-que-causaram-o-fim-da-exposicao-queermuseu.html>. Acesso

em: 02 abr. 2020.

O que acontece quando colocamos estas três imagens, de distintas temporalidades e contextos, em relação? Que ideias e imaginários ativam? Há conhecimentos prévios? Já visualizamos em algum lugar? O que sabemos sobre elas? Quais são as nossas suspeitas? Que pensamentos disparam?

A primeira (Figura 01), desde 1500 tem preconizado concepções de arte, sob a ótica da genialidade estrangeira, atrelada, inclusive, a perspectivas de cunho moral e religioso. O Homem Vitruviano produzido por Leonardo Da Vinci (1452-1519), apresenta o homem (branco, europeu) como ‘a medida de todas as coisas', conforme o antecessor Protágoras (481-411a.c.). O artista florentino continua sendo uma das principais referências quando se aborda 
o tema das artes visuais.

Se observamos isoladamente a representação de Da Vinci, ícone da alta cultura que atravessa séculos no mais alto pedestal da cultura ocidental (presente nos livros didáticos, referência em objetos cotidianos, adereços, roupas, e uma infinidades de produtos da indústria) certamente nosso olhar estará restrito àqueles dados disponibilizados pelos livros didáticos que envolvem a 'História da Arte' (quase sempre, a partir de uma estrutura linear, monolítica). Entretanto, quando o observamos em relação à imagem que aparece ao seu lado, estes aspectos superficiais tendem a ficar em segundo plano. $O$ que isso quer dizer?

Antecipo que não há o objetivo de desqualificar a importância de Da Vinci, muito menos de sua vasta produção artística. Muito pelo contrário, permanece o desejo de que continue participando dos repertórios que constituem nosso legado cultural e que contribuem para entendimento da nossa própria história. No entanto, é necessário pensar que consiste em uma, entre tantas outras, referências de artistas que merecem ocupar os espaços 'sagrados' que envolvem o estudo das artes e da cultura.

Retornando à pergunta: o quê acontece quando colocamos ao lado do ícone italiano uma a versão que a subverte e problematiza? A Mulher Vitruviana (Figura 02), pintura da artista afro-cubano americana Harmonia Rosales não está alocada aleatoriamente. Aparece em forma de pergunta, disposta a desafiar discursos prontos e reivindica que outras vozes (sobretudo as vozes das mulheres negras, historicamente silenciadas) possam participar destes repertórios visuais que são ensinados sob a ótica da cultura dominante.

Ao olhar para a pintura de Rosales, será que seguiremos olhando para Da Vinci a partir dos mesmos aspectos visuais? Nossa análise seguirá pelo viés do que é visto, ou poderá contemplar o que não vemos em uma imagem? Quem é a figura que está sendo apresentada? Pode um corpo nu de uma mulher negra ocupar o centro do universo? Quem decide? Quais são os efeitos de colocar no curso histórico das artes esta imagem? Podemos falar em silenciamento histórico a partir desta relação?

Acredito que podemos falar de muitas outras coisas a partir deste exercício, pois o que produz em cada sujeito que a observa, atravessa qualquer fronteira ou limite interpretativo. Possivelmente, precisaremos recorrer à história das segregações raciais, das violências de gênero contra as mulheres, o que nos implicará ampliar nossos repertórios (tanto visuais, 
quanto teóricos) disciplinares: precisaremos da sociologia, da filosofia, da antropologia, da psicologia, da geografia, da iconografia, dos estudos culturais, ou seja, transcender o caráter disciplinar ao qual nossas estruturas de aprendizado seguem organizadas.

E o que acontece quando adicionamos uma terceira imagem (Figura 03)? Neste caso, a obra censurada na Queermuseu: cartografias da diferença na arte brasileira, com curadoria de Gaudêncio Fidelis (exposição que foi alvo de protestos em Porto Alegre no ano de 2017 sob o pretexto de apologia à pedofilia, zoofilia e vilipêndio religioso). Nesta última 'Cruzando Jesus Cristo com Chiva', o que há de tão ameaçador a ponto de gerar protestos e manifestações proibindo sua visualização? Qual a potência do simbólico no imaginário social?

Sob o argumento de que algumas obras que integraram a exposição desrespeitavam símbolos e crenças, seguiram-se uma série de protestos, manifestações populares em frente ao espaço expositivo, redes sociais, e ameaças ao curador da exposição. Sem a pretensão de uma resposta, arrisco dizer que a arte contemporânea tenha como foco devolver-nos parte dos nossos repertórios a partir de linguagem metafórica: como um espelho, nos retorna, por meio das diversas materialidades, aquilo que atravessa as nossas cotidianidades: sonhos, desejos, imaginários que alimentamos a partir dos repertórios visuais que vamos coletando e guardando em nosso acervo da memória.

O aspecto inicial de seleção das três imagens está na sua estrutura visual: a representação de uma figura central com os membros superiores abertos para cima, na altura dos ombros, perpendicularmente ao torso - o que pode remeter tanto à estrutura da cruz (simbologia cristã) como a pirâmide invertida, através de uma composição verticalizada, estabelecida a partir de um ponto de equilíbrio central. De maneira geral, podemos dizer que estruturalmente, as três imagens estão muito próximas. Entretanto, quando adentramos no campo das representações simbólicas, os valores morais, se sobrepõem ao que está sendo mostrado, bem como aquilo que permanece invisível.

\subsubsection{Experimentação 2: subvertendo imaginários coletivos}

Assim como na experimentação anterior, a próxima configuração visual parte da estrutura formal de representações de afeto (beijos), extraídas de distintos tempos, contextos e linguagens. A primeira (Figura 04) é bastante 
conhecida, não apenas no universo das artes visuais, mas habita o imaginário popular. 'O beijo' de Gustav Klimt (1862-1918) aparece em objetos e utensílios diversos e certamente participa de nossos repertórios visuais. À segunda imagem (Figura 05), corresponde a uma ilustração correspondente a uma História em Quadrinhos da Marvel. A terceira (Figura 06), é uma fotografia da escultura do artista Constantin Brâncusi, do início do século XX.

A polêmica em torno da imagem central que apresenta dois homens jovens beijando-se, assim como a obra de Fernando Baril, presente na Queermuseu de Porto Alegre, foi alvo de protestos e boicote na Feira do Livro do Rio de Janeiro em 2019. O argumento do prefeito da cidade, Marcelo Crivella, era que o material trazia conteúdo 'sexual para menores' e que deveria ser retirado ou embalado em sacos plásticos de cor preta, para evitar o acesso visual.
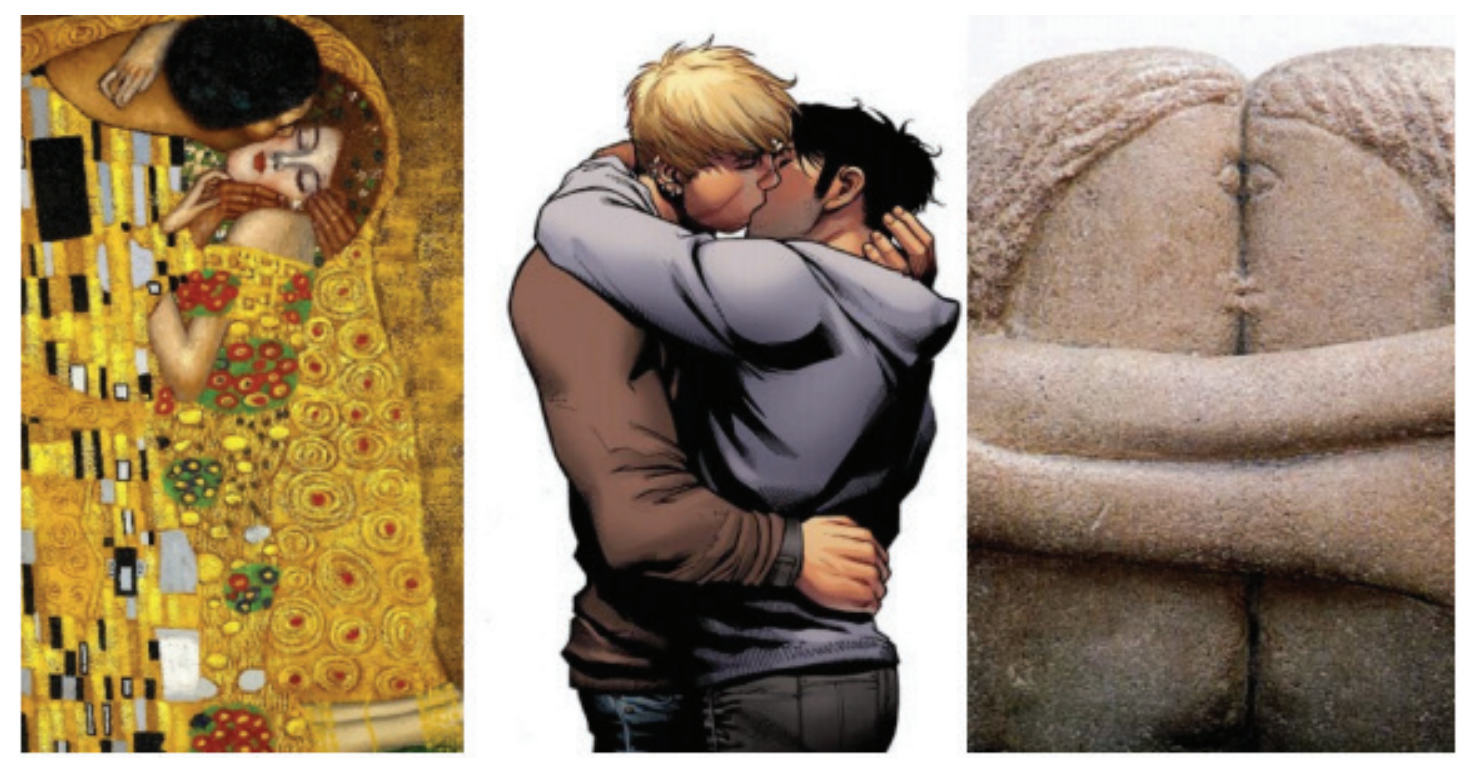

Figura 4: The kiss 1907-1908, Gustav Klimt,

Fonte: Disponível em: <https://www.wikiart.org/en/gustav-klimt/the-kiss-1908>.

Acesso em: 02 abr. 2020.

Figura 5: 2019, HQ Vingadores: A cruzada das crianças

Fonte: Disponível em: <https://revistagalileu.globo.com/Cultura/noticia/2019/og/vingadores-cruzada-das-criancas-conheca-hq-que-crivella-tentou-proibir-na-bienal.html>.

Acesso em: 02 abr. 2020.

Figura 6: 1907, Constantin Brâncusi

Fonte: Disponível em: <https://artschaft.com/2018/01/16/constantin-brancusi-the-kiss-1907/>. Acesso em: 02 abr. 2020.

Da mesma forma que o exercício anterior, se nos aproximamos de cada 
imagem isoladamente, nossas ideias se deslocam por outro viés e não adquirem a mesma potência e intensidade quando estão em conjunto. Lado a lado, elas rompem a hierarquia e sinalizam que esta prática pretende promover algumas relações. E o resultado deste diálogo pode trazer subsídios para práticas de subversão. Se tomamos a temática abordada pelas três imagens: um beijo entre duas pessoas, o que há de ameaçador na figura central? Por que este beijo deve ser proibido? Apesar de seguirem as mesmas estruturas formais (representação de duas pessoas em contato físico), o caráter simbólico envolve crença e valores éticos e morais que determinam 'o que pode' e 'o que não pode' ser mostrado, sob uma perspectiva.

Talvez, o maior problema em relação ao que a imagem central suscita, seja justamente o fato dela não estar naturalizada, assim como as duas representações: não costumamos ver esta imagem nas campanhas publicitárias que antecedem datas comemorativas, muito menos nos programas televisivos em rede aberta. Cenas de afeto entre pessoas do mesmo sexo continuam sendo pouco representadas e, consequentemente, seguem marginalizadas como 'imagens proibidas'.

Entretanto, ao subverter a ordem estabelecida, as imagens se tornam armas políticas contra regimes autoritários e estimulam o combate a concepções preconceituosas e discriminatórias que em determinados contextos correspondem a construções culturais mediadas pelas tradições e que definem e legitimam os papéis sociais. Neste sentido, ao confrontá-las, em um exercício como este em que colocamos imagens em relação, podemos movimentar a reflexão para que sejam revisitados os pré-conceitos. Para Raimundo Martins:

Trabalhar com imagens significa articular idas e vindas no tempo, inventando mundos e narrando histórias. É escolher e organizar fluxos imagéticos que se espalham no tempo, realidades múltiplas que se constroem, ficções que se tornam realidades. Ao pensar com imagens, buscamos possibilidades de promover outros espaços e ideias, extraindo dos fluxos do tempo oportunidades de ensinar, aprender, socializar, politizar, educar e criticar nos contrapondo a homogeneidades históricas, artísticas e educacionais. (MARTINS, 2013, p. 85)

Considerando as múltiplas temporalidades das imagens, sobretudo a perspectiva ideológica em que mecanismos operam na busca por fazer que se configure universal e legitimar algo que é, na realidade, parcial e par- 
ticular, fomentamos o debate e a reflexividade. Ou seja, dando-se conta das relações de poder intrínsecas à narrativa visual, ajuda a pensar o que significa ser aceito e legitimado como se aquilo que é cultural fosse de ordem natural.

As imagens estão situadas culturalmente e respondem a valores sociais. Em alguns casos, almejam a manutenção de imaginários dominantes e com interesses específicos. Sendo assim, é urgente fomentar o debate em torno aos dualismos (sujeito/objeto, razão/sensibilidade, macho/fêmea, bem/ mal) acompanhados da concepção de um sujeito pronto, estável, completo que deve ocupar papéis determinados e desempenhando suas funções de acordo com as normas.

\subsubsection{Experimentação 3: situando o lugar de fala}

Os aparatos que constituem a visão estão histórica e socialmente determinados e não podem ser estudados de forma independente destes fatores. Os artefatos visuais existem em relação a outros códigos visuais e reclamam outros sentidos além da visão e logram êxito como articulamos com distintos artefatos artísticos, como música e cinema.

A partir das representações de maior circulação em nossos contextos culturais, podemos problematizar quais modelos e/ou padrões corpóreos, estéticos são veiculados pelas distintas mídias ou artefatos visuais. Ou seja, examinar quais/como são as lentes que dispomos frente aos determinismos instituídos e institucionalizados dentro de cada conjuntura social.

Neste sentido, o clipe musical Apeshit dirigido por Ricky Saiz e protagonizado pela cantora Beyonce e pelo cantor Jay-Z, gravados dentro do Museu do Louvre em Paris há poucos anos, constitui-se artefato visual de transgressão e reivindicação da presença negra como protagonista das narrativas visuais.

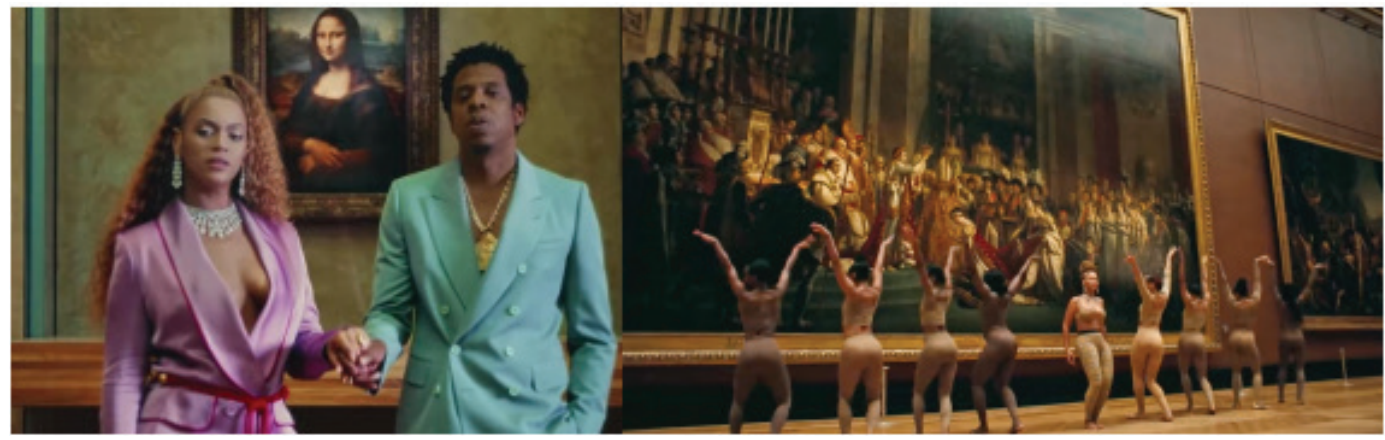

Figura 7: Frame de Apeshit: Beyonce e Jay-Z de costas para Monalisa - Museu do Louvre, Paris, França. 
Fonte: Disponível em: <https://www.huffpostbrasil.com/2018/06/19/7-detalhes-de-apeshit-clipe-de-beyonce-e-jay-z-que-talvez-voce-tenha-perdido_a_23462851/>. Acesso em: 02 abr. 2020.

Figura 8: Frame de Apeshit: Dançarinas frente à Coroação de Josefina - Museu do Louvre, Paris, França.

Fonte: Disponível em: <https://www.huffpostbrasil.com/2018/06/19/7-detalhes-de-apeshit-clipe-de-beyonce-e-jay-z-que-talvez-voce-tenha-perdido_a_23462851/>. Acesso em: 02 abr. 2020.

Nos frames do clipe musical da cantora (FIGURAS $07 \mathrm{E}$ 08), lançado em 2018, vemos um grupo de mulheres negras, enfrentando a grande narrativa da arte hegemônica. Entre várias tomadas realizadas dentro do imponente museu, a obra que remete à coroação de Josefina (também interpretada por alguns estudiosos como a coroação de Napoleão, obra do artista Jacques Luis-David, realizada entre 1806 e 1807 em dimensões gigantescas, assim como supremacia branca eurocêntrica), é desafiada pelas nove dançarinas que a partir dos distintos matizes e corporeidades, descortinam um passado de silenciamento cultural.

Ao subverter os principais ícones da 'História da Arte' presentes no museu, a artista coloca em movimento outras vozes ao posicionar-se de costas diante da Monalisa de Da Vinci, da Vênus de Milo, da Vitória de Samotrácia e da Esfinge de Tânis. As imagens intercaladas (obras de arte e coreografias) entram em cena colocando em relação os discursos hegemônicos da arte contrastados com a presença negra (e ausência) nestas representações. Inserido em um terreno de disputas, a obra da cantora emerge como potência mobilizadora de ideias, onde a arte se projeta a partir de experiências de sentido e confronto - de quem produz e de quem consome o artefato - contrapondo-se às distopias que buscam impor seus imaginários. Ao abandonar práticas passivas diante da experiência estética - por relações afetivas - materializam-se narrativas visuais que ocupam os mais variados locais - inclusive aqueles sacralizados que buscam seguir as apostilas do que deve ser visto e/ou mostrado.

\section{CONSIDERAÇÕES}

Propor a compreensão crítica das imagens significa partir do pressuposto de que nenhuma imagem é neutral. Isto é, partir da concepção de que toda produção visual é simbólica, e, ao ser materializada, corresponde 
a determinada intenção de quem a produz (ainda que 'intuitivamente'). Talvez, ao esmiuçarmos aquilo que entendemos como 'manifestação intuitiva' das nossas mentes, nos surpreenderemos ao perceber que correspondem a concepções forjadas pelos códigos culturais que nos constituem e atrelam-se à concepção de mundo que logramos construir. O recorte utilizado que delimita a 'captura' e materialização das imagens que produzimos e consumimos, vincula-se a 'uma forma de ver' e corresponde a um ponto de vista que encontra nas relações culturais suas raízes.

Atuamos em um mundo visualmente complexo, que, portanto, nos exige uma posição igualmente complexa na hora de articular nossas formas de comunicação e expressão. Diante de tantos caminhos possíveis, a perspectiva educativa da cultura visual, assim como a Investigação Baseada nas Artes apresentam-se como recurso teórico-metodológicos de grande relevância para estabelecermos posicionamentos críticos e que problematizam tudo aquilo que seja dado como verdade imutável.

Transgredir ou subverter os imaginários coletivos impostos pelas culturas dominantes é urgente, principalmente frente à ascensão político-partidária de extrema direita que desconsidera a perspectiva laica e democrática da sociedade brasileira. Vivemos tempos onde proliferam-se os discursos de ódio e preconceito que encontram suas bases em muitas referências endossadas pela hegemonia visual que segue reproduzindo versões estereotipadas da realidade.

Os encontros de aprendizagem múltipla e plural (terminologia que utilizo para denominar uma aula) em que imagens constituem pontos de partida, disparam e movimentam uma diversidade de conexões imensuráveis, pois ativa em cada sujeito participante o protagonismo da fala e do corpo. Aciona outros sentidos que possivelmente a palavra escrita, organizada em forma de texto, materializada em livros e apostilas, ou ainda, iluminada pela tela digital, não contempla. Como dito anteriormente: quando partimos do trabalho com/a partir de imagens, estamos lidando com outra natureza, outra forma de estabelecer relações (simbólicas, conceituais, interpretativas) com o mundo.

A instabilidade contemporânea nos empurra precipício abaixo se pensarmos em significados estáticos ou verdades imutáveis. Há sempre a suspeita de uma outra possibilidade de olhar o mesmo objeto. As certezas herdadas do positivismo não são suficientes para um mundo conflitivo que se alimenta da pluralidade e da diversidade. A partir destas condições - dinâ- 
micas, exploratórias e experimentais com/ a partir das imagens - professores e professoras que atuam na formação (sobretudo a formação docente nos distintos níveis e áreas) podem estimular o pensamento crítico, performático e emancipatório ao dar ênfase no protagonismo dos relatos visuais. Estas abordagens favorecem e potencializam a percepção crítica e interpretativa e estimula, a partir das experiências compartilhadas de visualização, esmiuçar tanto as inquietudes subjetivas, como as concepções políticas e ideológicas que as constituem.

\section{REFERÊNCIAS}

BAUMAN, Zygmunt. Ensaios sobre o conceito de cultura. Rio de Janeiro: Zahar, 2012. BOFF, Leonardo. A águia e a galinha. 43a ed. São Paulo: Vozes, 2006.

BRUNER, Jerome. Actos de significado: más allá de la revolución cognitiva. Madrid: Alianza, 1991.

HERNÁNDEZ, Fernando. Catadores da cultura visual. Porto Alegre: Mediação, 2007. HERNÁNDEZ, Fernando. Investigação baseada em arte: propostas para repensar a pesquisa em educação. (In) DIAS, Belidson; IRWIN, Rita L. (orgs.) Pesquisa educacional baseada em arte: a/r/tografia. Santa Maria: Ed. da UFSM, 2013.

MARTINS, Raimundo; TOURINHO, Irene (Orgs). Educação da cultura visual: conceitos e contextos. Santa Maria: Ed. da UFSM, 2011

MARTINS, Raimundo. Metodologias visuais: com imagens e sobre imagens. (In) DIAS, Belidson; IRWIN, Rita L. (orgs.) Pesquisa educacional baseada em arte: a/r/tografia. Santa Maria: Ed. da UFSM, 2013.

MOXEY, Keith. Teoria, práctica y persuasión: Estudios sobre historia del arte. Barcelona: Edicones del Serbal, 2004. 


\section{Lutiere Dalla Valle}

Doutor em Artes Visuais e Educação; Mestre em Artes Visuais e Educação, pela Universitat de Barcelona, Espanha; Mestre em Educação, Especialista em Arte e Visualidade, Licenciado e Bacharel em Desenho e Plástica - ambos pela Universidade Federal de Santa Maria onde atua como docente desde 2012. E-mail: lutiere@dallavalle.net.br 